\title{
Carbohydrate intake and resistance-based exercise: are current recommendations reflective of actual need?
}

\author{
Kurt A. Escobar $^{1 *}$, Trisha A. VanDusseldorp ${ }^{2}$ and Chad M. Kerksick ${ }^{3}$ \\ ${ }^{1}$ Department of Health, Exercise, and Sports Sciences, University of New Mexico, Albuquerque, NM 87131, USA \\ ${ }^{2}$ Department of Exercise Science and Sports Management, Kennesaw State University, Kennesaw, GA 30144, USA \\ ${ }^{3}$ School of Health Sciences, Lindenwood University, Saint Charles, MO 63301, USA \\ (Submitted 21 May 2016 - Final revision received 2 September 2016 - Accepted 11 October 2016 - First published online 20 December 2016)
}

\section{Abstract}

Substantial research has been completed examining the impact of carbohydrate (CHO) intake on endurance exercise, whereas its role in resistance-based exercise performance, adaptation and cell signalling has yet to be fully characterised. This empirical shortcoming has precluded the ability to establish specific $\mathrm{CHO}$ recommendations for resistance exercise. This results in recommendations largely stemming from findings based on endurance exercise and/or anecdotal evidence despite the distinct energetic demands and molecular responses mediating adaptation from endurance- and resistance-based exercise. Moreover, the topic of $\mathrm{CHO}$ and exercise has become one of polarising nature with divergent views - some substantiated, others lacking evidence. Current literature suggests a moderately high daily $\mathrm{CHO}$ intake (3-7 g/kg per d) for resistance training, which is thought to prevent glycogen depletion and facilitate performance and adaptation. However, contemporary investigation, along with an emerging understanding of the molecular underpinnings of resistance exercise adaptation, may suggest that such an intake may not be necessary. In addition to the low likelihood of true glycogen depletion occurring in response to resistance exercise, a diet restrictive in $\mathrm{CHO}$ may not be detrimental to acute resistance exercise performance or the cellular signalling activity responsible for adaptation, even when muscle glycogen stores are reduced. Current evidence suggests that signalling of the mammalian target of rapamycin complex 1, the key regulatory kinase for gene translation (protein synthesis), is unaffected by CHO restriction or low muscular glycogen concentrations. Such findings may call into question the current view and subsequent recommendations of $\mathrm{CHO}$ intake with regard to resistance-based exercise.

Key words: Protein synthesis: Mammalian target of rapamycin: Glycogen: Nutrient timing: Skeletal muscle hypertrophy

Macronutrient intake represents a potent modulator of acute exercise responses and chronic adaptations, exerting effects on resting metabolism, fuel utilisation during exercise, acute cell signalling and gene expression, and ultimately phenotype ${ }^{(1,2)}$. Carbohydrate $(\mathrm{CHO})$ serves as a key substrate for exercise, as well as mediates multiple molecular responses to endurance training ${ }^{(1-3)}$. It is well understood that high daily $\mathrm{CHO}$ intake is advantageous for endurance training, especially that of intense nature $^{(4,5)}$; however, specific recommendations of daily $\mathrm{CHO}$ have yet to be established for resistance-based exercise ${ }^{(6)}$. Moreover, the effects of $\mathrm{CHO}$ on the cellular responses to resistance exercise have yet to be fully characterised. The lack of empirical consensus on $\mathrm{CHO}$ intake and resistance exercise has resulted in recommendations largely stemming from endurance exercise and/or anecdotally based practices. This is problematic considering that resistance exercise often accounts for a substantial portion of athletes' training programmes and represents a highly practiced training mode within the recreational athletic community. This apparent shortage of evidence may lead an athlete or practitioner to unwarranted dietary practices, hindering training quality, adaptation and competitive performance.

Furthermore, the topic of $\mathrm{CHO}$ intake and exercise performance has become one of polarising nature. Low-CHO diets drawing inspiration from the Atkins Diet, such as the Paleolithic or 'Paleo' Diet, Zone Diet and ketogenic diets, first garnered popularity within the general population for weight management and general health purposes; however, such diets have found their way into the domain of exercise and sport nutrition $^{(7-12)}$ prior to their efficacy being established. The current climate in exercise and sport nutrition, particularly that in the general public and media, is one that seemingly creates a dichotomous view, where one is either 'anti-high CHO' or 'antilow CHO'. Some from the scientific community are currently strong proponents of these movements ${ }^{(9-11)}$. However, $\mathrm{CHO}$ need for training and performance is one of nuance and exists

Abbreviations: 1RM, one repetition maximum; AMPK, 5' AMP-activated protein kinase; CHO, carbohydrate; mTORC1, mammalian target of rapamycin complex 1.

*Corresponding author: K. A. Escobar, email kaescobar@unm.edu 
on a continuous spectrum, varying frequently while considering the athlete's mode of training, as well as the corresponding intensity and volume and inter-individual variability ${ }^{(13-15)}$. Most literature examining low-CHO diets has been focused on endurance exercise ${ }^{(9,10,16-18)}$. It is worth noting that despite a lack of evidence demonstrating an ergogenic benefit ${ }^{(19-22)}$ in addition to literature suggesting an increased risk of impaired high-intensity exercise capacity ${ }^{(16,18)}$, the appeal of a low-CHO diet for endurance performance has not subsided, attesting to the fervour surrounding this topic (the reader is referred to a review by Burke ${ }^{(18)}$ for a discussion of this topic).

Resistance-based exercise is metabolically distinct from endurance training and elicits a broadly different cascade of cellular events which underlie adaptation ${ }^{(23)}$. Resistance exercise outcomes are primarily instigated by mechanically based stress $^{(24,25)}$ rather than metabolic and energetic challenges as elicited by endurance exercise ${ }^{(23)}$. Therefore, $\mathrm{CHO}$ intake will likely influence adaptation to resistance-based exercise in a dissimilar manner compared with endurance exercise, although only a modest amount of literature exists to date pertaining to this question. Furthermore, $\mathrm{CHO}$ recommendations exclusively for resistance-based exercise are scarce, and literature addressing exercise nutrition oftentimes does not make any specific recommendations ${ }^{(26,27)}$. Typical recommendations suggest a moderately high $\mathrm{CHO}$ intake in the range of $3-7 \mathrm{~g} / \mathrm{kg}$ per $\mathrm{d}$ for resistance exercise trainees ${ }^{(14,28)}$; however, evidence appearing to challenge this paradigm exists ${ }^{(29-34)}$. Low-CHO diets may not be as detrimental as typically espoused, as investigations have demonstrated that $\mathrm{CHO}$ intakes less than the moderately high recommendation does not hinder acute resistance exercise performance $^{(30,32)}$ or the subsequent cellular responses responsible for adaptation, including translation initiation and myofibrillar protein synthesis ${ }^{(29,31)}$.

Scarce recommendations and recent findings call to question the actual $\mathrm{CHO}$ need for resistance-based exercise. This review will discuss the influence of $\mathrm{CHO}$ intake on resistance-based exercise using literature pertaining to acute resistance exercise performance and training outcomes. In addition, the underlying molecular responses to exercise and nutrient status will be discussed, including the influence of $\mathrm{CHO}$ on key cellular signalling pathways (e.g. 5 ' AMP-activated protein kinase (AMPK), Akt, mammalian target of rapamycin complex 1 (mTORC1)), as well as the implications on training-mediated adaptations.

\section{Literature review}

A review of the available literature was conducted using PubMed, Medline and SPORTDiscus databases, which were each searched for relevant keywords and phrases, alone or in combination, including carbohydrate, resistance exercise, glycogen, sports nutrition, performance, protein synthesis, supplementation, mTOR, AMPK, protein degradation, insulin, anabolism and so on. Given the nature of this topic, which includes elements of well-studied topics (i.e. CHO and endurance exercise, supplementation and protein synthesis, interaction of mTOR and AMPK and so on), substantial individual selection from high-return search results was required despite extensive manipulation with Boolean commands. Only studies published in an English-language refereed journal were included.

\section{Current recommendations for carbohydrate intake}

Individual macronutrient needs must be specific to the mode, volume, intensity and frequency of training, as well as accounting for inter-individual variability ${ }^{(13-15)}$. However, ranges of macronutrient recommendations for exercise do exist based on experimental observation, providing guidelines to assist in individualising nutrient intake ${ }^{(14,26,27)}$. With regard to $\mathrm{CHO}$, the American College of Sports Medicine, American Dietetic Association and the Dieticians of Canada ${ }^{(26)}$ recommend $\mathrm{CHO}$ targets ranging from 3 to $5 \mathrm{~g} / \mathrm{d}$ for low-intensity or skill-based activities to $8-12 \mathrm{~g} / \mathrm{kg}$ per $\mathrm{d}$ for very high training demands. The International Society of Sports Nutrition ${ }^{(27)}$ suggests $5-10 \mathrm{~g} / \mathrm{kg}$ per $\mathrm{d}$ for athletes involved in moderate and high volumes of intense training, and Costill \& Hargreaves ${ }^{(35)}$ recommend $8-10 \mathrm{~g} / \mathrm{kg}$ per $\mathrm{d}$ or $60-70 \%$ of daily energy intake during periods of heavy training. Interestingly, specific recommendations regarding $\mathrm{CHO}$ intake and resistance exercise are not made in any of this literature. It is well understood that such $\mathrm{CHO}-$ rich diets optimise performance in endurance-based training and competition ${ }^{(4,5)}$; however, the specific $\mathrm{CHO}$ requirements for individuals whose primary mode of training is based on resistance exercise have yet to be conclusively established $^{(6,13)}$. An acute bout of resistance exercise can reduce muscle glycogen content by approximately $25-40 \%{ }^{(36,37)}$, and thus it may be suggested that adequate daily $\mathrm{CHO}$ is warranted for glycogen repletion during periods of regular training. Slater \& Phillips ${ }^{(14)}$ recommend a moderate $3-5 \mathrm{~g} / \mathrm{kg}$ per $\mathrm{d}$ for strength and power athletes and $4-7 \mathrm{~g} / \mathrm{kg}$ per $\mathrm{d}$ for bodybuilders. Lambert et $a l^{(28)}$ recommends a $\mathrm{CHO}$ intake of $5-6 \mathrm{~g} / \mathrm{kg}$ per $\mathrm{d}$ or $55-60 \%$ of daily energy intake for bodybuilders. However, and of particular note, it has been observed that daily $\mathrm{CHO}$ intake considerably less than such recommendations does not impair resistance-based exercise performance ${ }^{(30,32,33,38-40)}$ or hinder the requisite post-exercise cellular signalling responses for adaptation ${ }^{(29,31,41,42)}$.

\section{Carbohydrate and resistance-based exercise performance}

The production and maintenance of muscular force during resistance exercise relies heavily on energy produced from the breakdown of phosphocreatine and muscle glycogen. Consequently, it may be argued that daily intake of $\mathrm{CHO}$ must be adequate to replete muscle glycogen stores ${ }^{(43)}$. However, if this is indeed the case (data presented in later sections may suggest otherwise), what constitutes 'adequate' for resistance-based exercise? While glycogen serves as a substrate during resistance training, the total energy expenditure of strength athletes is less than that of mixed sport and endurance athletes ${ }^{(13)}$, and experimental evidence has yet to confirm a minimum threshold of daily $\mathrm{CHO}$ intake for resistance trainees. Although Leveritt \& Abernathy ${ }^{(39)}$ reported a decrease in the number of back squat repetitions to failure following a low-CHO diet consisting of $1.26 \mathrm{~g} / \mathrm{kg}$ per $\mathrm{d}(111.9 \mathrm{~g} / \mathrm{d} ; 19.3 \%$ of energy intake) for $2 \mathrm{~d}$ in 
recreationally active subjects, the following investigations have demonstrated that modest, and even minimal, amounts of $\mathrm{CHO}$ may maintain resistance-based exercise performance (Table 1). Mitchell et $a l .{ }^{(30)}$ found that volumes (load $\times$ repetitions) of back squats, leg press and knee extensions were not compromised following $48 \mathrm{~h}$ of $0.4 \mathrm{~g} / \mathrm{kg}$ per d $\mathrm{CHO}(31.6 \mathrm{~g} / \mathrm{d} ; 4.1 \%$ of energy intake) compared with a high $\mathrm{CHO}$ intake of $7.7 \mathrm{~g} / \mathrm{kg}$ per $\mathrm{d}$ $(642.6 \mathrm{~g} / \mathrm{d} ; 80.2 \%$ of energy intake) in recreationally trained males. In a crossover study, Hatfield et al. ${ }^{(44)}$ investigated the effect of $4 \mathrm{~d}$ of $\mathrm{CHO}-$ loading on resistance training performance. Eight recreationally resistance-trained men consumed a diet of 50 and $80 \% \mathrm{CHO}$ and performed four sets of twelve repetitions of maximal effort squat jumps at $30 \%$ one repetition maximum (1RM) before and after each $\mathrm{CHO}$ intervention. There were no significant differences in peak power, mean power or total work accomplished in repetitive jump performance at $30 \%$ of 1RM between diets comprised of 50 and $80 \% \mathrm{CHO}$, respectively. In another crossover study by Dipla et $a l^{(33)}$, ten recreationally active women consumed a control diet consisting of $55 \% \mathrm{CHO}, 15 \%$ protein and $30 \%$ fat or a moderately low$\mathrm{CHO}$ diet of $30 \% \mathrm{CHO}, 40 \%$ protein and $30 \%$ fat for 1 week each and performed tests of upper- and lower-body strength. No differences were found between dietary interventions in isometric handgrip strength, handgrip endurance, peak torque of isokinetic knee extension or knee flexion. In addition, Sawyer et $a l^{(32)}$ imposed a hypoenergetic very-low-CHO $(30.77 \mathrm{~g} / \mathrm{d} ; 5.4 \%$ of daily kcal intake) diet on thirty-one trained individuals (sixteen men and fifteen women) for $7 \mathrm{~d}$ following $7 \mathrm{~d}$ of mixed diet $(265.40 \mathrm{~g} / \mathrm{kg} ; 40.7 \%$ of daily kcal intake) and measured pre- and post-intervention handgrip strength, vertical jump height, 1RM bench press, 1RM squat, upper-body power output and Wingate peak power. 1RM squat, vertical jump height and handgrip strength increased following the CHO-restricted diet, whereas bench press strength, upper-body power and Wingate peak power output were maintained. Van Zant et al. ${ }^{(40)}$ reported that 3 weeks of a moderate-CHO diet ( $42 \% \mathrm{CHO}, 40 \%$ fat and $18 \%$ protein) resulted in no difference in muscular strength or endurance as measured by isokinetic knee extension and flexion, bench press $1 \mathrm{RM}$ and repetitions to failure at $80 \%$ $1 \mathrm{RM}$ when compared with a high-CHO diet (62\% CHO, 20\% fat and $18 \%$ protein). Similarly, Paoli et al. ${ }^{(38)}$ reported that performance of squat jumps, countermovement jumps, consecutive countermovement jumps, push-ups, reverse grip chin ups and parallel bar dips test were maintained following $30 \mathrm{~d}$ of verylow-CHO ketogenic diet ( $4.5 \% \mathrm{CHO}, 54.8 \%$ fat and $40.7 \%$ protein) in nine elite gymnasts.

In addition to this human work, recent work involving a rodent model offers some of the only data investigating longerterm adaptations to resistance training while ingesting minimal amounts of $\mathrm{CHO}$. Roberts et $a l^{(34)}$ fed rats a ketogenic diet $(10 \cdot 3 \% \mathrm{CHO}, 20 \cdot 2 \%$ protein, $69.5 \%$ fat $)$ or a Western diet ( $42.7 \% \mathrm{CHO}, 15 \cdot 2 \%$ protein, $42 \cdot 0 \%$ fat) for 6 weeks during a resistance-training model consisting of resistance-loaded voluntary wheel running and measured muscular hypertrophy of the gastrocnemius. Following the 6-week diet and exercise intervention, both groups incurred an increase in myofibrillar protein content; however, no differences were observed between the ketogenic diet and the Western $\operatorname{diet}^{(34)}$.
The maintenance of strength and power performance in response to a short-term CHO-restricted diet (i.e. $2-4 \mathrm{~d})^{(39,44)}$ may not be unexpected, as this may be an insufficient time table to substantially decrease muscle glycogen stores. A number of the reported studies, however, did not collect skeletal muscle samples to assess intramuscular glycogen levels. In this respect, many of the aforementioned studies may only speculate as to whether the $\mathrm{CHO}$ intake manipulations altered muscle glycogen content. Moreover, the true risk of glycogen depletion during regular resistance exercise is unclear. An acute bout of resistance exercise can reduce glycogen concentrations by approximately $25-40 \%{ }^{(13,36,37,45)}$; however, even when no food or $\mathrm{CHO}$ is consumed in the post-exercise period, glycogen may be synthesised at an hourly rate of approximately $1 \cdot 3-11 \mathrm{mmol} / \mathrm{kg}$ wet weight ${ }^{(46)}$. Robergs et al. ${ }^{(36)}$ measured muscle glycogen in eight resistance-trained males before, immediately after and $2 \mathrm{~h}$ following six sets of six repetitions of leg extension at $70 \% 1 \mathrm{RM}$. Subjects were not fed during the 2 -h post-exercise period. Immediately post-exercise, glycogen concentrations were $61 \%$ of pre-exercise values. $2 \mathrm{~h}$ post-exercise, muscle glycogen concentrations were $79 \%$ of pre-exercise levels. In their review of nutrient timing, Aragon \& Schoenfeld ${ }^{(47)}$ suggest that incomplete resynthesis of muscular glycogen would not be a concern aside from the unlikely scenario of exhaustive training bouts of the same musculature occurring in recovery intervals $<24 \mathrm{~h}$. Considering that many resistance-training programmes utilise $2-3 \mathrm{~d}$ recovery periods between training muscle groups, it is likely that even modest amounts of $\mathrm{CHO}$ are capable of replenishing glycogen stores between training bouts of particular musculature.

\section{Nutrient intake, resistance exercise and cell signalling}

Macronutrient intake is capable of modulating the acute regulatory processes that underlie cell signalling, gene expression and thus adaptation (Fig. 1) ${ }^{(1)}$. CHO intake and subsequent intramuscular glycogen concentrations play a role in the energy status and signalling activity of skeletal muscle, namely by influencing the activity of $\mathrm{AMPK}^{(1,2,48,49)}$. AMPK is a metabolite-sensing kinase that monitors cellular energy status, regulating the activity of catabolic and anabolic pathways, as well as the transcription of several exercise-responsive genes ${ }^{(23,48,50-52)}$. Although AMPK activity is crucial to support muscular contraction ${ }^{(48)}$, AMPK is capable of exerting an inhibitory effect on the cellular signalling pathways involved in the adaptive responses to resistance-based exercise, namely protein synthesis ${ }^{(53,54)}$. AMPK up-regulates protein degradation pathways including autophagy and the ubiquitin proteasome pathway ${ }^{(55,56)}$ while serving as a negative regulator of the mTORC1 ${ }^{(54,57,58)}$. mTORC1 is a central regulatory kinase involved in cell growth and protein synthesis and is stimulated by amino acids, as well as mechanical loading, such as that elicited by resistance exercise ${ }^{(24,25)}$. Within the immediate post-exercise period ( $0-1 \mathrm{~h})$ following resistance exercise, the intracellular environment transitions from an initial degradation phase to an anabolic phase mediated by decreased AMPK activity and up-regulation of mTORC1 activity and translation initiation ${ }^{(29,34,57,59,60)}$. AMPK contains glycogen-binding sites ${ }^{(49)}$, leading to the hypothesis that this 
Table 1. A summary of investigations examining carbohydrate $(\mathrm{CHO})$ intake manipulation and acute resistance-based exercise performance

\begin{tabular}{|c|c|c|c|c|}
\hline Authors & Participants & Resistance exercise protocol & $\mathrm{CHO}$ intervention & Performance outcomes \\
\hline Dipla et al. ${ }^{(33)}$ & $\begin{array}{l}10 \text { recreationally active women; } \\
\text { crossover design }\end{array}$ & $\begin{array}{l}\text { Isokinetic knee flexion and extension: } 3 \text { maximal efforts, } \\
4 \text { sets of } 16 \text { maximal extension-flexion cycles at } \\
120 \% \mathrm{~s} \text { with } 60 \mathrm{~s} \text { intervals } \\
\text { Handgrip dynamometry: } 3 \text { maximal efforts, hold to } \\
\text { failure at } 80 \% \text { maximal handgrip strength }\end{array}$ & $\begin{array}{l}\text { Randomised order } \\
7 \mathrm{~d} \text { of } 30 \% \mathrm{CHO}, 40 \% \text { protein, } 30 \% \text { fat } \\
7 \mathrm{~d} \text { of } 55 \% \mathrm{CHO}, 15 \% \text { protein, 30\% fat } \\
\text { 3-week washout period }\end{array}$ & $\begin{array}{l}\leftrightarrow \text { Peak torque, total work or fatigue in knee flexion } \\
\text { and extension between } \mathrm{CHO} \text { conditions } \\
\leftrightarrow \text { Handgrip maximal strength or fatigue } \\
\text { between CHO conditions }\end{array}$ \\
\hline Hatfield et al. ${ }^{(4)}$ & $\begin{array}{l}8 \text { recreationally resistance-trained } \\
\text { men; crossover design }\end{array}$ & Squat jump: 4 sets of 12 repetitions at $30 \% 1 \mathrm{RM}$ & $\begin{array}{l}\text { Randomised order } \\
4 \mathrm{~d} \text { of } 50 \% \mathrm{CHO} \\
4 \mathrm{~d} \text { of } 80 \% \mathrm{CHO} \\
\text { 2-week washout period }\end{array}$ & $\begin{array}{l}\leftrightarrow \text { Squat jump peak power, mean power or total } \\
\text { work between CHO conditions }\end{array}$ \\
\hline $\begin{array}{l}\text { Leveritt \& } \\
\quad \text { Abernathy } \\
\end{array}$ & $\begin{array}{l}6 \text { recreationally active } \\
(1 \text { female, } 5 \text { male })\end{array}$ & $\begin{array}{l}\text { Isoinertial squat: } 3 \text { sets to failure at } 80 \% 1 \mathrm{RM} \\
\text { Isokinetic knee extension: } 5 \text { sets of } 5 \text { repetitions, each } \\
\text { set at different contractile speeds }(1.05,2 \cdot 09,3.14 \text {, } \\
4.19 \text { and } 5.24 \mathrm{rad} / \mathrm{s})\end{array}$ & $\begin{array}{l}\text { Glycogen depletion protocol: } 60 \mathrm{~m} \text { of cycling at } \\
75 \% \text { of } \mathrm{PVO}_{2} \text { followed by four } 1 \text {-min bouts at } \\
100 \% \text { of } \mathrm{PVO}_{2} \\
2 \mathrm{~d} \text { of } 1.26 \text { (SD } 0.5) \mathrm{g} / \mathrm{kg} \text { per } \mathrm{d} \text { of } \mathrm{CHO}\end{array}$ & $\begin{array}{l}\downarrow \text { Isoinertial squats to failure in CHO-restricted } \\
\text { condition } v \text {. control condition ( } 33.0 \text { v. } 41 \cdot 83 \\
\text { repetitions, respectively) } \\
\leftrightarrow \text { Torque in isokinetic knee extension between } \\
\text { CHO conditions }\end{array}$ \\
\hline Mitchell et al. ${ }^{(30)}$ & $\begin{array}{l}11 \text { resistance-trained males; } \\
\text { crossover design }\end{array}$ & $\begin{array}{l}\text { Back squat: } 5 \text { sets to failure at } 15 \mathrm{RM} \\
\text { Leg press: } 5 \text { sets to failure at } 15 \mathrm{RM} \\
\text { Knee extension: } 5 \text { sets to failure at } 15 \mathrm{RM}\end{array}$ & $\begin{array}{l}\text { Glycogen depletion protocol: } 60 \mathrm{~m} \text { of cycling at } \\
70 \% \text { VO } \\
\mathrm{VO}_{2 \max } \text { followed by } 6 \text { sprints at } 115 \% \\
\mathrm{Randomised} \mathrm{order} \\
2 \mathrm{~d} \text { of } 0.4 \mathrm{~g} / \mathrm{kg} \text { per } \mathrm{d}(31.6(\mathrm{SD} 1.6) \mathrm{g} / \mathrm{d}) . \\
225.6 \mathrm{~g} / \mathrm{d} \text { protein, } 229.7 \mathrm{~g} / \mathrm{d} \text { fat } \\
2 \mathrm{~d} \text { of } 7.7 \mathrm{~g} / \mathrm{kg} \text { per } \mathrm{d}(642.6(\mathrm{SD} 21.1) \mathrm{g} / \mathrm{d}), \\
84.8 \mathrm{~g} / \mathrm{d} \text { protein, } 33.0 \mathrm{~g} / \mathrm{d} \text { fat }\end{array}$ & $\begin{array}{l}\leftrightarrow \text { Back squat total work completed } \\
\text { (load } \times \text { repetitions) between } \mathrm{CHO} \text { conditions } \\
\leftrightarrow \text { Leg press total work completed } \\
\text { (load } \times \text { repetitions) between } \mathrm{CHO} \text { conditions } \\
\leftrightarrow \text { Knee extension total work completed } \\
\text { (load } \times \text { repetitions) between } \mathrm{CHO} \text { conditions }\end{array}$ \\
\hline Paoli et al..$^{(38)}$ & 9 elite male gymnasts & $\begin{array}{l}\text { Squat jump (body weight) } \\
\text { Countermovement jump (CMJ) } \\
\text { Reverse grip chins ups to failure } \\
\text { Push-ups to failure } \\
\text { Parallel bar dips to failure }\end{array}$ & $\begin{array}{l}30 \mathrm{~d} \text { of } 4.5 \% \text { (22 (SD } 2.3) \mathrm{g} / \mathrm{d} \text { ) } \mathrm{CHO}, 40.7 \% \\
\text { protein, } 54.8 \% \text { fat, followed by } \\
30 \mathrm{~d} \text { of } 46.8 \% \text { (266.1 (SD } 30.8 \text { ) g/d) } \mathrm{CHO} \text {, } \\
14.7 \% \text { protein, } 38.5 \% \text { fat } \\
\text { Continued normal, controlled training; } \\
\text { intensity and volume were similar during } \\
\text { dietary interventions } \\
\text { 3-month washout period }\end{array}$ & $\begin{array}{l}\leftrightarrow \text { Squat jump height between } \mathrm{CHO} \text { conditions } \\
\leftrightarrow \text { CMJ height between } \mathrm{CHO} \text { conditions } \\
\leftrightarrow \text { Reverse grip chin up repetitions to failure } \\
\text { between CHO conditions } \\
\leftrightarrow \text { Push-ups to failure between } \mathrm{CHO} \text { conditions } \\
\leftrightarrow \text { Parallel dip repetitions to failure between } \\
\text { CHO conditions }\end{array}$ \\
\hline Sawyer et al. ${ }^{(32)}$ & $\begin{array}{l}31 \text { resistance-trained ( } 15 \text { females, } \\
16 \text { males); crossover design }\end{array}$ & $\begin{array}{l}\text { 1RM back squat } \\
\text { 1RM bench press } \\
\text { Maximum upper-body power output (bench press): } 65 \% \\
1 \mathrm{RM}+20 \text { psi for men, } 10 \mathrm{psi} \text { for women } \\
\text { Lower-body power: CMJ } \\
\text { Anaerobic power: } 30-\mathrm{s} \text { Wingate } \\
\text { Handgrip strength (dynamometry): } 3 \text { maximal efforts }\end{array}$ & $\begin{array}{l}7 \mathrm{~d} \text { of } 40.7 \% \mathrm{CHO}, 22 \cdot 2 \% \text { protein, } 34.4 \% \text { fat } \\
\text { followed by } \\
7 \mathrm{~d} \text { of } 5.4 \%(<50 \mathrm{~g} / \mathrm{d}) \mathrm{CHO}, 35.1 \% \text { protein, } \\
53.6 \% \text { fat }\end{array}$ & $\begin{array}{l}\uparrow 1 \mathrm{RM} \text { back squat in } \mathrm{CHO}-\text {-restricted condition from } \\
\text { habitual diet }(+0.94 \mathrm{~kg}) \\
\leftrightarrow 1 \mathrm{RM} \text { bench press between } \mathrm{CHO} \text { conditions } \\
\leftrightarrow \text { Maximum upper-body power between } \mathrm{CHO} \\
\text { conditions } \\
\uparrow \mathrm{CMJ}(+1.2 \mathrm{~cm}) \text { in } \mathrm{CHO} \text {-restricted condition } \\
\leftrightarrow \text { Wingate peak power between } \mathrm{CHO} \\
\text { conditions } \\
\uparrow \text { Handgrip strength in } \mathrm{CHO} \text {-restricted condition } \\
\text { from habitual diet }(+2.6 \mathrm{~kg})\end{array}$ \\
\hline Van Zant et al. ${ }^{(40)}$ & $\begin{array}{l}18 \text { ( } 6 \text { strength-trained, } 6 \text { aerobically } \\
\text { trained, } 6 \text { sedentary) men; } \\
\text { crossover design }\end{array}$ & $\begin{array}{l}\text { Isokinetic knee extension and flexion: } 3 \text { repetitions } \\
\text { (at } 1.05,3.14 \text { and } 4.19 \mathrm{rad} / \mathrm{s} \text { ) } \\
\text { 1RM bench press }\end{array}$ & $\begin{array}{l}\text { Randomised order } \\
3 \text { weeks of } 42 \% \mathrm{CHO}, 18 \% \text { protein, } \\
40 \% \text { fat } \\
3 \text { weeks of } 62 \% \mathrm{CHO}, 18 \% \text { protein, } \\
20 \% \text { fat } \\
\text { Continued habitual exercise/activity } \\
\text { patterns during dietary intervention }\end{array}$ & $\begin{array}{l}\leftrightarrow \text { Peak torque, and total work in knee extension } \\
\text { and flexion between } \mathrm{CHO} \text { conditions } \\
\leftrightarrow 1 \mathrm{RM} \text { bench press between } \mathrm{CHO} \text { conditions }\end{array}$ \\
\hline
\end{tabular}

RM, repetition maximum; $\mathrm{PVO}_{2}$, peak cycle ergometer $\mathrm{VO}_{2}$. 


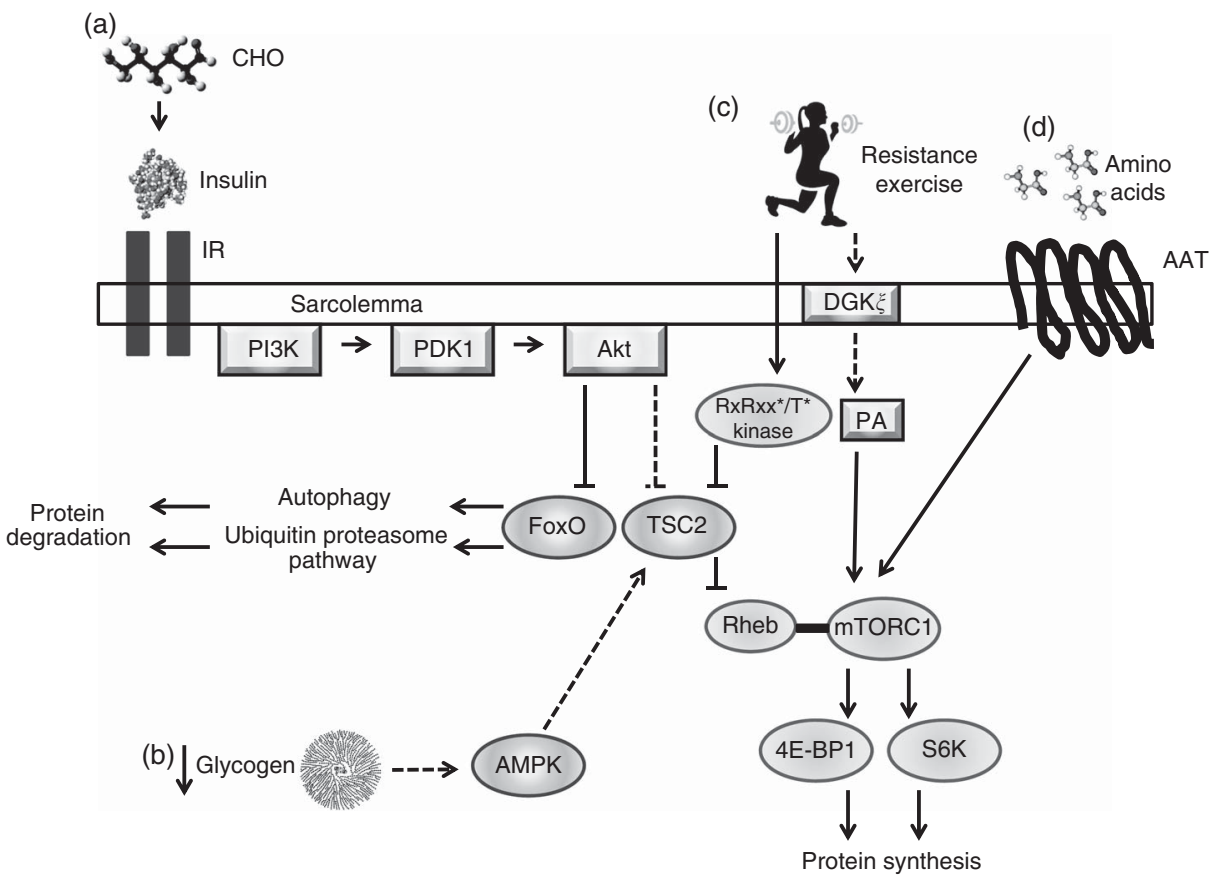

Fig. 1. Simplified illustration of cell signalling pathways associated with protein synthesis and degradation in skeletal muscle resulting from nutrient intake, glycogen concentrations and mechanical loading. (a) Carbohydrate ( $\mathrm{CHO}$ ) ingestion results in the secretion of insulin from the pancreas into the blood, which binds to insulin receptors (IR) on the sarcolemma, activating the phosphatidylinositol-3-OH kinase (PI3K)-Akt pathway. Akt inhibits forkhead box O (FoxO) activity by promoting its exportation from the nucleus into the cytoplasm and inducing its degradation, inhibiting protein degradation systems autophagy and the ubiquitin proteasome pathway. Akt removes tuberous sclerosis complex 2 (TSC2) from the lysosomal membrane, allowing for mammalian target of rapamycin complex 1 (mTORC1) to interact with its activator Ras homologue enriched in bran (Rheb) at the lysosome. Activation of mTORC1 results in increased activity of ribosomal kinases S6 (S6k; p70S6K, p90S6K) and inhibition of eukaryotic initiation factor 4E-binding protein (4E-BP1), leading to protein synthesis. ------, Physiological concentrations of insulin have not been shown to increase protein synthesis in human muscle. (b) Low muscle glycogen levels may increase 5' AMP-activated protein kinase (AMPK) activity, leading to an enhanced activity of TSC2 and inhibition of mTORC1 activity. -...... Unestablished effect of glycogen concentrations on AMPK in human skeletal muscle at rest or during and after resistance exercise; inhibitory effect of AMPK on mTORC1 may not impair mTORC1 activity in human skeletal muscle following resistance exercise or amino acid feeding. (c) Heavy mechanical loading (i.e. resistance exercise) activates a currently unknown kinase, which phosphorylates TSC2 within a RxRxx ${ }^{\star} /{ }^{*}$ motif resulting in its translocation from the lysosome, allowing mTORC1 to bind with Rheb. Phosphatidic acid (PA) activates mTORC1, possibly by direct binding to the

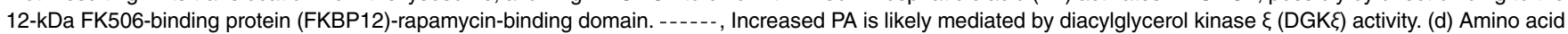
transporters (AAT) uptake amino acids into the sarcoplasm. An increase in intracellular amino acid levels facilitate translocation of mTORC1 to the lysosomal surface mediated by the Rag family of G-proteins where it can interact with Rheb. $\longleftarrow,---\rightarrow$, Stimulatory response; $\vdash$, i---, inhibitory response.

protein complex may be allosterically modified by muscle glycogen status $^{(48,49,61)}$. While currently the physiological significance of glycogen-mediated AMPK regulation is unclear ${ }^{(62-66)}$, it has been speculated that very-low-CHO diets, such as ketogenic diets ${ }^{(67)}$, and low-glycogen concentrations ${ }^{(1,48,63)}$ may result in up-regulated AMPK activity and thus may not be recommended for incurring muscular hypertrophy given its inhibitory effects on mTORC $1^{(54,57)}$. Roberts et $a l .{ }^{(34)}$ reported no difference in basal $\alpha \mathrm{AMPK}^{\mathrm{Thr} 172}$ phosphorylation, as well as no differences at 90, 180, $270 \mathrm{~min}$ post-resistance exercise in rats following 6 weeks of an isoenergetic intake of either a ketogenic diet (10.3\% CHO, 20.2\% protein, $69.5 \%$ fat $)$ or a Western diet $(42.7 \% \mathrm{CHO}, 15.2 \%$ protein, $42.0 \%$ fat). In addition, although commencing endurance exercise with low-glycogen concentrations results in increased AMPK activity when compared with normal concentrations ${ }^{(3,63,68)}$, this relationship has yet to be established with resistance exercise. However, current evidence suggests that intramuscular glycogen content does not augment basal AMPK activity ${ }^{(29,64,65)}$

An in vitro study by McBride et al. ${ }^{(49)}$ demonstrated that treatment of oligosaccharides allosterically inhibited AMPK; however, an investigation by Polekhina et $a l^{(69)}$ found that glycogen did not inhibit purified rat liver AMPK. Moreover, human studies have yielded conflicting results regarding the influence of glycogen content and AMPK activity at rest. Wojtaszewski et $a l^{(63)}$ reported that a low glycogen concentration of $163 \mathrm{mmol} / \mathrm{kg}$ dry mass resulted in a $160 \%$ increase in $\alpha 1 \mathrm{AMPK}$ activity and a $145 \%$ increase in $\alpha 2 \mathrm{AMPK}$ activity at rest compared with $909 \mathrm{mmol} / \mathrm{kg}$ dry mass in endurance-trained men. However, other investigations have reported no differences in resting AMPK activity in recreationally active men ${ }^{(64,65)}$, moderately trained men ${ }^{(66)}$ and physically fit men ${ }^{(29)}$, amid modest concentrations of muscle glycogen (approximately $170 \mathrm{mmol} / \mathrm{kg}$ dry mass). Furthermore, reduced muscular glycogen concentrations do not appear to hinder post-resistance exercise protein synthesis ${ }^{(29,31,41)}$.

\section{Insulin and protein metabolism}

Dietary CHO may also affect protein metabolism by influencing blood insulin levels ${ }^{(70-72)}$. However, although in vitro studies have shown that insulin stimulates muscle protein synthesis via the phosphoinositide 3-kinase (PI3K)-Akt pathway ${ }^{(73-75)}$, it appears that insulin holds only a permissive role rather than a 
modulatory role in enhancing muscle protein synthesis ${ }^{(76)}$. In a systemic review and meta-analysis, Abdulla et al. ${ }^{(76)}$ found that insulin exerted no stimulatory effect on muscle protein synthesis in the twenty-five studies used. In healthy individuals, the protein synthetic effect of insulin only becomes significant when amino acid delivery is increased; this effect is reduced or nonexistent when amino acid delivery is reduced, even at supraphysiological concentrations of insulin ${ }^{(76)}$. Thus, the co-ingestion of $\mathrm{CHO}$ with amino acids/protein, as may be practiced by resistance trainees, would provide no additional muscle protein synthetic benefit $v$. amino acids/protein alone given protein content is adequate (approximately $25 \mathrm{~g})^{(77,78)}$. Staples et $a l .{ }^{(78)}$ reported no difference in muscle protein synthesis or eukaryotic initiation factor 4E-binding protein (4E-BP1) and p70S6K phosphorylation at 1 and $3 \mathrm{~h}$ postresistance exercise after ingestion of $25 \mathrm{~g}$ of whey protein and $50 \mathrm{~g}$ of maltodextrin $v .25 \mathrm{~g}$ of whey protein alone $30 \mathrm{~min}$ postexercise. This coincides with data showing that mTORC1 activity in skeletal muscle is unaltered by systemic growth factors that act through the PI3K-pathway, such as insulin and insulin-like growth factor-1, and that post-exercise muscle protein synthesis is an intrinsically mediated process ${ }^{(24,79-81)}$.

With regard to muscle protein degradation, however, Abdulla et $a l^{(76)}$ concluded that insulin reduces degradation rates and facilitates an overall positive net protein balance. This suppressive effect is mediated by the PI3K-Akt pathway, which is activated by the binding of insulin to its transmembrane insulin receptor on the sarcolemma and initiates translocation of the proteins to the cell membrane ${ }^{(25)}$. Akt inhibits forkhead box $\mathrm{O}$, a transcription factor implicated with gene expression associated with the ubiquitin proteasome pathway $^{(56,82-85)}$ and autophagy ${ }^{(56,86,87)}$, two major pathways of protein degradation, by promoting its exportation from the nucleus into the cytoplasm and inducing its degradation $^{(50,84)}$. This insulin-mediated reduction in muscle protein breakdown appears to be more potent when amino acids are scarce ${ }^{(76,88,89)}$. Although Bird et al. ${ }^{(88,89)}$ report a synergistic effect of $\mathrm{CHO}$ and amino acid ingestion on attenuating protein degradation, in the presence of adequate amino acid availability, the co-ingestion of $\mathrm{CHO}$ with protein following resistance exercise does not appear to result in further suppression of muscle protein breakdown ${ }^{(77,78,90)}$. Staples et al. ${ }^{(78)}$ showed that except for postresistance exercise phosphorylation of Akt, after ingestion of $25 \mathrm{~g}$ of whey protein and $50 \mathrm{~g}$ of maltodextrin, there were no differences in muscle protein degradation or acetyl-CoA carboxylase- $\beta$, a surrogate marker for AMPK, v. $25 \mathrm{~g}$ of whey protein alone. Reports of enhanced hypertrophy while co-ingesting $\mathrm{CHO}$ and protein post-resistance exercise ${ }^{(91-93)}$ are likely then attributed to amino acid content rather than a combinatory effect of amino acids and $\mathrm{CHO}$ and that the resultant insulinogenic response appears to be superfluous in the presence of an adequate provision of amino acids ${ }^{(77,78)}$

Low carbohydrate intake, muscle glycogen concentrations and cell signalling in response to resistance exercise

The influence of chronic low $\mathrm{CHO}$ intakes on post-resistance exercise anabolism has yet to be well characterised. Roberts et $a l .{ }^{(34)}$ conducted a pioneering mechanistic investigation of the effects of a low-CHO ketogenic diet on resistance exercise signalling activity using rats fed either a ketogenic diet $(10 \cdot 3 \%$ $\mathrm{CHO}, 20.2 \%$ protein, $69.5 \%$ fat) or a Western diet ( $42.7 \% \mathrm{CHO}$, $15.2 \%$ protein, $42.0 \%$ fat) for 6 weeks. The study showed that a low-CHO ketogenic diet does not impair the acute anabolic responses to resistance exercise. At 90, 180 and 270 min postexercise, similar rates of muscle protein synthesis and phosphorylation of downstream mTORC1 targets, rps6 and 4E-BP1 in the gastrocnemius were observed in ketogenic-diet-fed rats and Western-diet-fed rats. Phosphorylation of $\alpha \mathrm{AMPK}^{\text {Thr172 }}$ did not increase in either group. There were also no differences in total RNA content, a proxy measure for protein synthetic capacity, or measures of hypertrophy between groups following the 6-week intervention, as both groups incurred significant increases from pre-training levels. It is worth noting, however, that there were no differences in muscle glycogen between groups.

Few data exist pertaining to the cell signalling activity following acute resistance exercise amidst divergent muscular glycogen concentrations. It has been hypothesised that reduced glycogen concentrations augment AMPK activity ${ }^{(1,61)}$ and may blunt mTORC1 activity ${ }^{(67)}$. In a crossover study by Creer et $a l^{(31)}$, eight experienced cyclists underwent 2 consecutive days of glycogen-depleting cycling exercise after having consumed either a very low ( $2 \%$ of energy intake; $26.0 \mathrm{~g} / \mathrm{d}$ ) or high intake of $\mathrm{CHO}$ ( $80 \%$ of energy intake; $1042.2 \mathrm{~g} / \mathrm{d}$ ) leading to intramuscular glycogen concentrations of 174 and $591 \mathrm{mmol} / \mathrm{kg}$ dry mass, respectively. After a 12-h fast, subjects then performed a resistance training bout of three sets of ten repetitions of bilateral knee extension at $70 \%$ of $1 \mathrm{RM}$. Muscle biopsies were taken immediately before exercise, immediately postexercise and $10 \mathrm{~min}$ post-exercise. Pre-exercise phosphorylation levels of mTORC1 targets, $\mathrm{Akt}^{\mathrm{Ser} 473}$ (upstream) and p90S6K $\mathrm{K}^{\text {Thr573 }}$ (downstream) and $\mathrm{mTORC1}^{\text {Ser2448 }}$ were not affected by glycogen status at rest. Similarly, phosphorylation levels were not different for any of these proteins between the two glycogen conditions immediately following exercise. In addition, p906SK was unaffected by glycogen status at $10 \mathrm{~min}$ post-resistance exercise. However, resistance training in a lowglycogen state resulted in a reduced phosphorylation of Akt compared with completing the same resistance exercise bout with high levels of intramuscular glycogen, but mTORC1 activity was not affected. These findings are partially explained by activity of the load-induced mTORC1 pathways that operate independent of $\mathrm{Akt}^{(25,94,95)}$. Extracellular signal-regulated

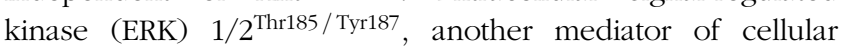
growth, was not influenced by glycogen content at rest, immediately post-exercise or $10 \mathrm{~min}$ post-exercise. These data suggest that the post-resistance exercise mTORC1 activity is not affected by divergent muscular glycogen concentrations. A study by Churchley et al. ${ }^{(41)}$ investigated the effect of glycogen content on myogenic gene transcription immediately and $3 \mathrm{~h}$ post-resistance exercise. Seven strength-trained males underwent a one-legged exhaustive exercise bout to lower muscle glycogen (193 mmol/kg dry mass), whereas the contralateral leg maintained normal glycogen stores $(435 \mathrm{mmol} / \mathrm{kg}$ dry mass). Participants then completed another bout of resistance training the following day after a 10-12-h fast; each resistance exercise 
bout consisted of eight sets of five repetitions of leg press (one leg at a time) at $80 \% 1 \mathrm{RM}$. There was no significant difference in mRNA abundance of myogenin (MyoG), myogenic differentiation factor D (MyoD) or insulin-like growth factor-1 at rest (before resistance training) between the low and normal leg. Interestingly, mRNA content of atrophy-related genes, atrogin and muscle-specific RING finger (MuRF), was significantly higher in the normal-glycogen leg at rest compared with the lowglycogen leg. In response to resistance training, there were no differences in mRNA abundance of MyoG, MyoD or insulin-like growth factor- 1 between legs $3 \mathrm{~h}$ post-exercise. There was also no difference in mRNA abundance of atrogin, MuRF or myostatin, demonstrating that glycogen content does not influence transcriptional activity of either hypertrophy- or atrophy-related genes in response to an acute bout of resistance exercise.

Furthermore, Camera et $a l .{ }^{(29)}$ also reported similar findings using a near-identical one-legged glycogen-depleting protocol and a resistance training bout of eight sets of five repetitions of leg press (one leg at a time) at $80 \% 1 \mathrm{RM}$ the following day. Muscle biopsy samples were collected before exercise and 1 and $4 \mathrm{~h}$ post-exercise. However, of the sixteen physically fit male subjects used, eight subjects consumed a protein-CHO beverage ( $20 \mathrm{~g}$ of whey protein, $40 \mathrm{~g}$ of maltodextrin), whereas eight subjects ingested a placebo (water, artificial sweetener) immediately after exercise and $2 \mathrm{~h}$ following completion of the exercise bout. Glycogen content in the reduced glycogen condition was 176 and $184 \mathrm{mmol} / \mathrm{kg}$ dry mass, whereas glycogen content in the normal glycogen condition was 382 and $383 \mathrm{mmol} / \mathrm{kg}$ dry mass in the placebo and supplement groups, respectively. At rest, no difference in mTORC1 ${ }^{\text {Ser2448 }}$ phosphorylation was reported between legs or groups, whereas $\mathrm{Akt}^{\mathrm{Ser} 473}$ and $\mathrm{p} 70 \mathrm{~S} 6 \mathrm{~K}^{\mathrm{Thr} 389}$ phosphorylation levels were higher in the low leg compared with the normal leg in both placebo and supplement groups. Resting $\mathrm{S} 6^{\mathrm{Ser} 235 / 236}$ phosphorylation was significantly greater in the low leg than in the normal leg in the supplement group, but there was no difference in AMPK $\alpha^{\text {Thr172 }}$ phosphorylation or atrogin and myostatin mRNA abundance at rest. At both post-exercise time points, no difference in atrogin and myostatin mRNA abundance was seen in the placebo group; however, these same genes were significantly up-regulated in the low-glycogen leg during the post-exercise period in the supplement group. The investigators speculated that rather than preserving muscle protein in the absence of nutrients as in the placebo/fasted condition the provision of exogenous $\mathrm{CHO}$ and amino acids in the supplement group amidst the presence of low glycogen may have initiated the muscle remodelling activity. There was no difference in AMPK, Akt, p70S6K and S6 phosphorylation between legs in either group 1 and $4 \mathrm{~h}$ post-exercise. mTORC1 phosphorylation was not affected by glycogen status in the placebo group at either post-exercise time point. mTORC1 phosphorylation was significantly increased in both the low-glycogen leg and normal-glycogen leg post-exercise in the supplement group; however, the effect was more pronounced in the normal leg when compared with the glycogen-depleted leg at both $1 \mathrm{~h}$ (approximately 4 -fold $v$. approximately 11-fold, respectively) and $4 \mathrm{~h}$ post-exercise (approximately 1 -fold $v$. approximately 4-fold, respectively). It is worth noting that activity of downstream targets (p7056K, s6) was not different between legs, and thus the observed increase in mTORC1 phosphorylation in the low-glycogen leg was sufficient enough to initiate activation of the downstream proteins associated with translation initiation. Further and seemingly most telling, there was no difference in myofibrillar protein synthesis rate between legs in either group during the $1-4 \mathrm{~h}$ recovery period (Table 2 ).

These data seem to suggest that low pre-exercise muscle glycogen concentrations (approximately $181.8 \mathrm{mmol} / \mathrm{kg}$ dry mass) have negligible effects on the molecular signalling activity of cell growth and protein synthesis in the recovery phase following resistance training. The measured regulatory proteins associated with muscle protein synthesis including mTORC1 and its upstream and downstream targets, as well as rates of protein synthesis, were found to be unaffected by divergent levels of glycogen. The one exception was observed in the investigation by Creer $e t a l .{ }^{(31)}$, which reported a reduced phosphorylation of Akt 10 min post-exercise. However, this may simply be related to the timing of post-exercise biopsies $(10 \min v .1,3 \text { and } 4 \mathrm{~h})^{(29)}$. Moreover, this may be of no consequence to resistance-exerciseinduced muscle protein synthesis given that mechanicalstimulated mTORC1 activity occurs independent of the Akt pathway $^{(24,81)}$. Therefore, it appears that the resistance-exerciseinduced activation of anabolic cell signalling is potent enough to overcome any potential inhibitory signalling activity elicited by low glycogen concentrations, should any exist. This is consistent with the observation that the repressive effects of AMPK on anabolic signalling activity and muscle protein synthesis in humans appears to be negligible following exercise, especially in the later stages of recovery (i.e. $1-4 \mathrm{~h})^{(29,57,59,60,96,97)}$.

\section{Amino acids, resistance exercise and protein balance}

Protein feeding acutely increases the free amino acid pool and exerts a profound effect on muscle protein balance by increasing protein synthesis and reducing protein degradation ${ }^{(98-102)}$. A provision of essential amino acids (6-12 g), particularly leucine (3-6g), favourably influences muscle protein synthesis over a period of hours ${ }^{(77,100,101,103)}$, by not only serving as substrates to be incorporated into new proteins but by up-regulating mTORC1 activity as well ${ }^{(104-106)}$. When intracellular amino acid content increases, amino acids accumulate within the lysosome, initiating the translocation of mTORC1 to the membrane of the lysosome where it interacts with its activator Ras homologue enriched in bran (Rheb) ${ }^{(25,107,108)}$. Although it has yet to be fully characterised, amino-acid-stimulated movement of mTORC1 to the lysosome is mediated by the Rag family of G-proteins (RagA, B, $\mathrm{C}, \mathrm{D})$ where the presence of amino acids results in the activation of this complex, which binds to raptor, the regulatory protein of mTORC1, and recruits mTORC1 to the lysosome through its interaction with the Ragulator on the lysosomal membrane ${ }^{(24,109)}$. Amino acids can also inhibit autophagy ${ }^{(105,106,110,111)}$ and the ubiquitin proteasome pathway ${ }^{(112,113)}$, two intracellular pathways implicated with the degradation of cellular proteins. Even modest amounts of intact proteins (approximately 20-25 g) rich in essential amino and/or branched-chain amino acids are capable of optimally stimulating muscle protein synthesis ${ }^{(77,114,115)}$. 
Table 2. A summary of investigations examining the acute post-exercise cellular responses associated with protein synthesis after commencing resistance exercise with divergent levels of muscle glycogen

\begin{tabular}{|c|c|c|c|c|c|c|}
\hline Authors & Participants & $\begin{array}{l}\text { Nutritional/supplementation } \\
\text { intervention }\end{array}$ & Resistance exercise protocol & Pre-exercise glycogen concentrations & & Post-exercise cellular responses \\
\hline \multirow[t]{9}{*}{$\begin{array}{l}\text { Camera } \\
\text { et al. }\end{array}$} & \multirow{9}{*}{$\begin{array}{l}16 \text { physically fit males } \\
\text { (8 subjects consumed } \\
\text { post-exercise pro-CHO } \\
\text { supplement, 8 subjects } \\
\text { consumed PL) }\end{array}$} & \multirow{9}{*}{$\begin{array}{l}\sim 1 \mathrm{~g} / \mathrm{kg} \mathrm{CHO} \text { evening meal } \\
\text { following glycogen depletion } \\
\text { protocol } \\
10 \mathrm{~h} \text { fast before trial } \\
\text { Immediately and } 2 \mathrm{~h} \text { post- } \\
\text { exercise } 500 \mathrm{ml} \text { of } \\
\text { Pro-CHO: } 20 \mathrm{~g} \text { whey protein } \\
\quad 40 \mathrm{~g} \text { maltodextrin }(n 8) \text { or } \\
\mathrm{PL}: \text { water + artificial sweetener } \\
(n 8)\end{array}$} & \multirow{9}{*}{$\begin{array}{l}8 \text { sets of } 5 \text { repetitions of } \\
\text { unilateral leg press at } \\
80 \% 1 R M \\
\text { One leg with low glycogen } \\
\text { (LOW), one leg normal } \\
\text { (NORM) glycogen }\end{array}$} & \multirow[t]{9}{*}{$\begin{array}{l}\text { LOW Pro-CHO: } 184 \mathrm{mmol} / \mathrm{kg} \mathrm{DM} \\
\text { LOW PL: } 176 \mathrm{mmol} / \mathrm{kg} \text { DM } \\
\text { NORM Pro-CHO: } 382 \mathrm{mmol} / \mathrm{kg} \mathrm{DM} \\
\text { NORM PL: } 383 \mathrm{mmol} / \mathrm{kg} \mathrm{DM}\end{array}$} & $\begin{array}{l}\text { AMPK Thr172 }^{\text {Ansphorylation }} \\
\text { phosp }\end{array}$ & $\begin{array}{l}1 \mathrm{~h}: \leftrightarrow \text { between LOW PL and NORM PL } \\
\leftrightarrow \text { between LOW Pro-CHO and NORM Pro-CHO } \\
4 \mathrm{~h}: \leftrightarrow \text { between LOW PL and NORM PL } \\
\leftrightarrow \text { between LOW Pro-CHO and NORM Pro-CHO }\end{array}$ \\
\hline & & & & & $\begin{array}{l}\text { Akt }^{\text {Ser473 }} \\
\text { phosphorylation }\end{array}$ & $\begin{array}{l}1 \mathrm{~h}: \leftrightarrow \text { between LOW PL and NORM PL } \\
\leftrightarrow \text { between LOW Pro-CHO and NORM Pro-CHO } \\
4 \mathrm{~h}: \leftrightarrow \text { between LOW PL and NORM PL }\end{array}$ \\
\hline & & & & & $\begin{array}{l}\text { mTORC1 Ser2448 } \\
\text { phosphorylation }\end{array}$ & $\begin{array}{c}1 \mathrm{~h}: \leftrightarrow \text { between LOW PL and NORM PL } \\
\uparrow \text { in NORM Pro-CHO v. LOW Pro-CHO } \\
4 \mathrm{~h}: \leftrightarrow \text { between LOW PL and NORM PL } \\
\uparrow \text { in NORM Pro-CHO v. LOW Pro-CHO }\end{array}$ \\
\hline & & & & & $\begin{array}{l}\text { p70S6K } \mathrm{K}^{\mathrm{Th}} 389 \\
\text { phosphorylation }\end{array}$ & $\begin{array}{l}1 \mathrm{~h}: \leftrightarrow \text { between LOW PL and NORM PL } \\
\leftrightarrow \text { between LOW Pro-CHO and NORM Pro-CHO } \\
4 \mathrm{~h}: \leftrightarrow \text { between LOW PL and NORM PL }\end{array}$ \\
\hline & & & & & $\mathrm{S}^{\mathrm{Se} 2335 / 236}$ & $\begin{array}{l}\leftrightarrow \text { between LOW Pro-CHO and NORM Pro-CHO } \\
1 \mathrm{~h}: \leftrightarrow \text { between LOW PL and NORM PL }\end{array}$ \\
\hline & & & & & phosphorylation & $\begin{array}{l}\leftrightarrow \text { between LOW Pro-CHO and NORM Pro-CHO } \\
4 \mathrm{~h}: \leftrightarrow \text { between LOW PL and NORM PL } \\
\leftrightarrow \text { between LOW Pro-CHO and NORM Pro-CHO }\end{array}$ \\
\hline & & & & & $\begin{array}{l}\text { Atrogin-1 mRN } \\
\text { Aabundance }\end{array}$ & $\begin{array}{l}1 \mathrm{~h}: \leftrightarrow \text { between LOW PL and NORM PL } \\
\leftrightarrow \leftrightarrow \text { between LOW Pro-CHO and NORM Pro-CHO } \\
4 \mathrm{~h}: \leftrightarrow \text { between LOW PL and NORM PL } \\
\\
\uparrow \text { in LOW Pro-CHO v. NORM Pro-CHO }\end{array}$ \\
\hline & & & & & $\begin{array}{l}\text { Myostatin mRNA } \\
\text { abundance }\end{array}$ & $\begin{array}{l}1 \mathrm{~h}: \leftrightarrow \text { between LOW PL and NORM PL } \\
\text { ↔ between LOW Pro-CHO and NORM Pro-CHO } \\
4 \mathrm{~h}: \stackrel{\leftrightarrow}{\leftrightarrow} \text { between LOW PL and NORM PL } \\
\uparrow \text { in LOW Pro-CHO v. NORM Pro-CHO }\end{array}$ \\
\hline & & & & & $\begin{array}{l}\text { Myofibrillar protein } \\
\text { synthesis }\end{array}$ & $\begin{array}{l}1 \mathrm{~h}: \leftrightarrow \text { between LOW PL and NORM PL } \\
\leftrightarrow \text { between LOW Pro-CHO and NORM Pro-CHO } \\
4 \mathrm{~h}: \leftrightarrow \text { between LOW PL and NORM PL } \\
\text { ↔ between LOW Pro-CHO and NORM Pro-CHO }\end{array}$ \\
\hline \multirow[t]{6}{*}{$\begin{array}{l}\text { Churchley } \\
\text { et al. }{ }^{(4)}\end{array}$} & \multirow[t]{6}{*}{$\begin{array}{l}7 \text { highly resistance-trained } \\
\text { males }\end{array}$} & \multirow{6}{*}{$\begin{array}{l}\sim 1 \mathrm{~g} / \mathrm{kg} \mathrm{CHO} \text { evening meal } \\
\text { following glycogen depletion } \\
\text { protocol } \\
10-12 \mathrm{~h} \text { fast before trial }\end{array}$} & \multirow{6}{*}{$\begin{array}{l}8 \text { sets of } 5 \text { repetitions of } \\
\text { unilateral leg press at } \\
80 \% 1 \mathrm{RM} \\
\text { One leg with low glycogen } \\
\text { (LOW), one leg normal } \\
\text { (NORM) glycogen }\end{array}$} & \multirow[t]{6}{*}{$\begin{array}{l}\text { LOW: } 193 \text { (SD 29) mmol/kg DM } \\
\text { NORM: } 435 \text { (SD } 87 \text { ) } \mathrm{mmol} / \mathrm{kg} \mathrm{DM}\end{array}$} & $\begin{array}{l}\text { MyoG mRNA } \\
\text { abundance }\end{array}$ & $3 \mathrm{~h}: \leftrightarrow$ between LOW and NORM \\
\hline & & & & & $\begin{array}{l}\text { MyoD mRNA } \\
\text { abundance }\end{array}$ & $3 \mathrm{~h}: \leftrightarrow$ between LOW and NORM \\
\hline & & & & & $\begin{array}{l}\text { IGF-1 mRNA } \\
\text { abundance }\end{array}$ & $3 \mathrm{~h}: \leftrightarrow$ between LOW and NORM \\
\hline & & & & & Atrogin mRNA & $3 \mathrm{~h}: \leftrightarrow$ between LOW and NORM \\
\hline & & & & & $\begin{array}{l}\text { MuRF mRNA } \\
\text { Muance }\end{array}$ & $3 \mathrm{~h}: \leftrightarrow$ between LOW and NORM \\
\hline & & & & & $\begin{array}{c}\text { abundance } \\
\text { Myostatin mRNA }\end{array}$ & $3 \mathrm{~h}: \leftrightarrow$ between LOW and NORM \\
\hline \multirow[t]{4}{*}{$\begin{array}{l}\text { Creer } \\
\quad \text { et al. }\end{array}$} & \multirow[t]{4}{*}{$\begin{array}{l}8 \text { experienced male cyclists; } \\
\text { crossover design }\end{array}$} & \multirow{4}{*}{$\begin{array}{l}\text { LOW: } 2 \% \mathrm{CHO}, 18 \% \text { Pro, } \\
80 \% \text { fat } \\
\text { HIGH: } 80 \% \text { CHO, } 13 \% \text { Pro, } \\
7 \% \text { fat during } 2 \text { d glycogen } \\
\text { depletion protocol } \\
12 \mathrm{~h} \text { fast before trial }\end{array}$} & \multirow{4}{*}{$\begin{array}{l}3 \text { sets of } 10 \text { repetitions of } \\
\text { bilateral knee extension at } \\
70 \% \text { of } 1 \mathrm{RM}\end{array}$} & \multirow[t]{4}{*}{$\begin{array}{l}\text { Low: } 174 \text { (SD 24) } \mathrm{mmol} / \mathrm{kg} \mathrm{DM} \\
\text { High: } 591 \text { (SD 35) } \mathrm{mmol} / \mathrm{kg} \text { DM }\end{array}$} & $\begin{array}{l}\text { abundance } \\
\mathrm{Akt}^{\mathrm{Ser} 473} \\
\text { phosphorylation }\end{array}$ & $\begin{array}{l}\text { Im: } \leftrightarrow \text { between Low and High } \\
10 \mathrm{~min}: \leftrightarrow \text { between Low and High }\end{array}$ \\
\hline & & & & & $\begin{array}{l}\text { mTOR Ser2448 }_{\text {phosphorylation }}\end{array}$ & $\begin{array}{l}\text { Im: } \leftrightarrow \text { between Low and High } \\
10 \text { min: } \leftrightarrow \text { between Low and High }\end{array}$ \\
\hline & & & & & $\begin{array}{l}\text { p90S6K } K^{\text {Thr573 }} \\
\text { phosphorylation }\end{array}$ & $\begin{array}{l}\text { Im: } \leftrightarrow \text { between Low and High } \\
10 \mathrm{~min}: \leftrightarrow \text { between Low and High }\end{array}$ \\
\hline & & & & & $\begin{array}{l}\text { ERK } 1 / 2^{\text {Thr1 } 185 / \text { Thr1 } 187} \\
\text { phosphorylation }\end{array}$ & $\begin{array}{l}\text { Im: } \leftrightarrow \text { between Low and High } \\
10 \mathrm{~m}: \leftrightarrow \text { between Low and High }\end{array}$ \\
\hline
\end{tabular}

$\overline{\mathrm{CHO}}$, carbohydrate; PL, placebo; Pro, protein; AMPK, 5' AMP-activated protein kinase; mTORC1, mammalian target of rapamycin complex 1; MyoG, myogenin; MyoD, myogenic differentiation factor D; IGF-1, insulin-like growth factor-1; MuRF, muscle-specific RING finger; Im, immediately; ERK, extracellular signal-regulated kinase. 
Indeed, it has been observed that a 20 -g dose of protein every $3 \mathrm{~h}$ over a 12 -h period substantially increases synthesis rates of protein in skeletal muscle and promotes overall positive balance of protein in the body ${ }^{(98,116)}$. This effect seems to be unaltered by $\mathrm{CHO}$ intake. Harber et $a l .{ }^{(117)}$ showed that $7 \mathrm{~d}$ of a very-low-CHO-higher-protein diet $(5 \% \mathrm{CHO}, 60 \%$ fat and 35\% protein) increased muscle fractional synthetic rate 2 -fold compared with an isoenergetic ( $117 \mathrm{~kJ} / \mathrm{kg}$ body mass $(28 \mathrm{kcal} / \mathrm{kg}$ body mass)) traditional Western diet (60\% CHO, 30\% fat, $10 \%$ protein) in healthy subjects. Furthermore, a study by Robinson et al. ${ }^{(118)}$ measured whole-body protein turnover for $9 \mathrm{~h}$ in seven men who were fed hourly isoenergetic beverages providing $70 \%$ of total energy from $\mathrm{CHO}$ or protein. All seven men completed both trials (in addition to a fasted trial). Protein synthesis in response to the high-CHO beverage was $132.2 \mathrm{~g}$, whereas degradation was $109.8 \mathrm{~g}$, resulting in a net nitrogen balance of $+21.4 \mathrm{~g}$ over the $9 \mathrm{~h}$. However, protein synthesis in response to the high-protein beverage was $243.9 \mathrm{~g}$, and a degradation of $78.9 \mathrm{~g}$, resulting in a net nitrogen balance of $+165 \mathrm{~g}$. Corresponding $\mathrm{CHO}$ intake during trials was 291 and $62 \mathrm{~g}$ for the high-CHO trial and high-protein trials, respectively. These data in addition to the documented modest effect of $\mathrm{CHO}$ ingestion on protein degradation $(76,88,89)$ demonstrate that sufficient protein intake can result in a positive muscle protein balance, which is necessary for hypertrophy, and is not predicated on $\mathrm{CHO}$ ingestion.

Finally, as mentioned earlier, resistance exercise significantly affects muscle protein metabolism. Resistance training elicits an intrinsic stimulatory response to mTORC1, independent of the PI3K-Akt pathway, by activating a currently unknown kinase that phosphorylates tuberous sclerosis complex 2 (TSC2) within an RxRxxS*/T* motif and initiates its translocation away from the lysosome allowing mTORC1 to interact with Rheb ${ }^{(24,25)}$. In addition, phosphatidic acid, a glycerophospholipid, also mediates load-induced mTORC1 activation, potentially through direct binding to the 12-kDa FK506-binding protein (FKBP12)rapamycin-binding domain of mTORC1; however, the origin of synthesis of phosphatidic acid in response to mechanical loading also has yet to be identified ${ }^{(24,25,95)}$. Resistance exercise results in elevated rates of protein synthesis immediately postexercise and up to $24-48 \mathrm{~h}$ following an acute bout ${ }^{(57,119-122)}$. Furthermore, it has been well established that this response can be enhanced by protein ingestion in the proximal hours before

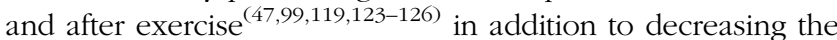
protein degradation observed following resistance exercise when performed in the fasted state ${ }^{(127)}$. Given that skeletal muscle mass is primarily dictated by the regulation of protein synthesis $^{(25,90)}$, the synergistic effect of timely and adequate protein intake in combination with resistance training appears to be sufficient enough to promote activation of the requisite molecular machinery for facilitating skeletal muscle hypertrophy ${ }^{(24,25)}$ irrespective of $\mathrm{CHO}$ intake and/or glycogen status ${ }^{(29,31,41)}$.

\section{Discussion}

Despite the traditional view that regularly training individuals should consume a CHO-rich diet ${ }^{(27,128)}$, need should be determined by the influence of $\mathrm{CHO}$ on the acute energetic support of exercise, as well as the implications on the cellular signalling activity that underlie chronic adaptation. Of which, resistance exercise is metabolically distinct from endurance exercise and the expression of adaption-based genes is mediated through divergent pathways, thus $\mathrm{CHO}$ need may also be distinct. It has been suggested that individuals who engage in regular resistance training should consume a moderate to high daily intake of $\mathrm{CHO}$ (i.e. $3-7 \mathrm{~g} / \mathrm{kg}$ per $\mathrm{d})^{(14,28)}$; however, recent investigation suggest that intakes of $\mathrm{CHO}$ lower than what is commonly recommended may still allow for optimal resistance exercise adaptations ${ }^{(13)}$. As such, the current paradigm of $\mathrm{CHO}$ requirements with regular resistance training appears to be inconsistent with experimental observations yielded from such studies.

First, it has not been observed that regular resistance-based exercise bears the potential to lead to true glycogen depletion. And, given that glycogen replenishment may occur even in an unfed state ${ }^{(36,46)}$, it is likely that even modest daily intakes of $\mathrm{CHO}$ are capable of restoring glycogen stores. In addition, it has been demonstrated that during periods of low $\mathrm{CHO}$ intake and/or low muscle glycogen concentrations, resistance exercise performance is maintained (i.e. 1RM, training volume) ${ }^{(30,32)}$, whereas early data may also suggest unhindered hypertrophy $^{(34)}$. Furthermore, anabolic cell signalling ${ }^{(29,31)}$, gene transcription $^{(41)}$ and muscle protein synthesis ${ }^{(29)}$ also appear unimpaired. The investigations of intracellular signalling activity corresponding to glycogen content and resistance training suggest that resistance exercise- and amino-acid-mediated protein synthetic responses are unaffected by low levels of muscle glycogen ${ }^{(29,31,41)}$. Given that adaptation to training results from the cumulative effect of transient increases in mRNA transcripts that encode for proteins after each successive exercise bout ${ }^{(23)}$, the unimpaired resistance exercise and/or amino acid feeding-induced up-regulation of regulatory proteins (mTORC1, p70S6K, 4E-BP1) associated with gene translation, gene transcription and protein synthesis may allow for uncompromised adaptation. Further, insulin appears to play only a permissive role in muscle protein synthesis rather than an augmentative one ${ }^{(76)}$. And, while insulin may reduce protein degradation $^{(76)}$, an adequacy of amino acids may accomplish the same effect while concomitantly promoting protein synthesis $^{(76-78)}$. Thus, it appears that the insulinogenic response elicited by $\mathrm{CHO}$ ingestion is not required to activate or enhance the protein synthetic response in the presence of sufficient amino acids ${ }^{(76-78)}$

Further inquiry is needed to establish the role of $\mathrm{CHO}$ intake in resistance-based exercise adaptation including hypertrophy and strength, as limited research is currently available. Moreover, many discrepancies lie between the works that currently exist, particularly with regard to nutritional intervention implementation. Not all studies used isoenergetic diets, nor were all investigations matched for protein intake. Additionally, many of the studies did not provide meals to subjects during interventions and relied upon self-reported diet adherence. Further, the relatively small samples used in these studies may have prohibited small, but meaningful, effects from being detected between $\mathrm{CHO}$ and glycogen conditions. Because of these limitations, it is premature at the present time to amend $\mathrm{CHO}$ recommendations, nonetheless these data do call into 
question the current view of $\mathrm{CHO}$ need as both a substrate for resistance training and a modulator of the cellular signalling activity that underlie resistance training adaptation.

\section{Acknowledgements}

This research received no specific grant from any funding agency, commercial or not-for-profit sectors.

K. A. E., T. A. V., C. M. K. developed the topic for review; K. A. E. and T. A. V. conducted the review and drafted the paper; C. M. K. provided direction and feedback during drafting of the paper, including edits of various drafts of the article.

The authors declare that there are no conflicts of interest.

\section{References}

1. Hawley JA, Burke LM, Phillips SM, et al. (2011) Nutritional modulation of training-induced skeletal muscle adaptations. J Appl Physiol 110, 834-845.

2. Hawley JA, Tipton KD \& Millard-Stafford ML (2006) Promoting training adaptations through nutritional interventions. J Sports Sci 24, 709-721.

3. Bartlett JD, Hawley JA \& Morton JP (2015) Carbohydrate availability and exercise training adaptation: too much of a good thing? Eur J Sport Sci 15, 3-12.

4. Achten J, Halson SL, Moseley L, et al. (2004) Higher dietary carbohydrate content during intensified running training results in better maintenance of performance and mood state. J Appl Physiol 96, 1331-1340.

5. Bergstrom J, Hermansen L, Hultman E, et al. (1967) Diet, muscle glycogen and physical performance. Acta Physiol Scand 71, 140-150.

6. Campbell B (2013) Sports Nutrition: Enhancing Athletic Performance. Boca Raton, FL: CRC Press.

7. Wilson PB (2016) Nutrition behaviors, perceptions, and beliefs of recent marathon finishers. Phys Sportsmed 44, 1-10.

8. Cordain LJF (2005) The Paleo Diet for Atbletes. Emmanus, PA: Rodale Press.

9. Noakes T, Volek JS \& Phinney SD (2014) Low-carbohydrate diets for athletes: what evidence? Br J Sports Med 48, 1077-1078.

10. Volek JS, Noakes T \& Phinney SD (2015) Rethinking fat as a fuel for endurance exercise. Eur J Sports Sci 15, 13-20.

11. Volek JS \& Phinney SD (2012) The Art and Science of Low Carbohydrate Performance. Miami, FL: Beyond Obesity.

12. Sisson M \& Kearns B (2016) Primal Endurance: Escape Chronic Cardio and Carbohydrate Dependency and Become a Fat Burning Beast! New York: Primal Nutrition Inc.

13. Helms ER, Aragon AA \& Fitschen PJ (2014) Evidence-based recommendations for natural bodybuilding contest preparation: nutrition and supplementation. J Int Soc Sports Nutr 11, 20.

14. Slater G \& Phillips SM (2011) Nutrition guidelines for strength sports: sprinting, weightlifting, throwing events, and bodybuilding. J Sports Sci 29, Suppl. 1, S67-S77.

15. Goedecke JH, St Clair Gibson A, Grobler L, et al. (2000) Determinants of the variability in respiratory exchange ratio at rest and during exercise in trained athletes. Am J Physiol Endocrinol Metab 279, E1325-E1334.

16. Burke LM \& Hawley JA (2002) Effects of short-term fat adaptation on metabolism and performance of prolonged exercise. Med Sci Sports Exerc 34, 1492-1498.
17. Burke LM \& Kiens B (2006) 'Fat adaptation' for athletic performance: the nail in the coffin? J Appl Physiol 100, 7-8.

18. Burke LM (2015) Re-examining high-fat diets for sports performance: did we call the 'nail in the coffin' too soon? Sports Med 45, Suppl. 1, S33-S49.

19. Phinney SD, Bistrian BR, Evans WJ, et al. (1983) The human metabolic response to chronic ketosis without caloric restriction: preservation of submaximal exercise capability with reduced carbohydrate oxidation. Metabolism 32, 769-776.

20. Goedecke JH, Christie C, Wilson G, et al. (1999) Metabolic adaptations to a high-fat diet in endurance cyclists. Metabolism 48, 1509-1517.

21. Vogt M, Puntschart A, Howald H, et al. (2003) Effects of dietary fat on muscle substrates, metabolism, and performance in athletes. Med Sci Sports Exerc 35, 952-960.

22. Zajac A, Poprzecki S, Maszczyk A, et al. (2014) The effects of a ketogenic diet on exercise metabolism and physical performance in off-road cyclists. Nutrients 6, 2493-2508.

23. Hawley JA, Hargreaves M, Joyner MJ, et al. (2014) Integrative biology of exercise. Cell 159, 738-749.

24. Watson K \& Baar K (2014) mTOR and the health benefits of exercise. Semin Cell Dev Biol 36, 130-139.

25. Marcotte GR, West DW \& Baar K (2015) The molecular basis for load-induced skeletal muscle hypertrophy. Calcif Tissue Int 96, 196-210.

26. Thomas DT, Erdman KA \& Burke LM (2016) Position of the Academy of Nutrition and Dietetics, Dietitians of Canada, and the American College of Sports Medicine: Nutrition and Athletic Performance. J Acad Nutr Diet 116, 501-528.

27. Kreider RB, Wilborn CD, Taylor L, et al. (2010) ISSN exercise \& sport nutrition review: research \& recommendations. J Int Soc Sports Nutr 7, 7.

28. Lambert CP, Frank LL \& Evans WJ (2004) Macronutrient considerations for the sport of bodybuilding. Sports Med $\mathbf{3 4}$, 317-327.

29. Camera DM, West DW, Burd NA, et al. (2012) Low muscle glycogen concentration does not suppress the anabolic response to resistance exercise. J Appl Physiol 113, 206-214.

30. Mitchell JB, DiLauro PC, Pizza FX, et al. (1997) The effect of preexercise carbohydrate status on resistance exercise performance. Int J Sport Nutr 7, 185-196.

31. Creer A, Gallagher P, Slivka D, et al. (2005) Influence of muscle glycogen availability on ERK1/2 and Akt signaling after resistance exercise in human skeletal muscle. $J$ Appl Physiol 99, 950-956.

32. Sawyer JC, Wood RJ, Davidson PW, et al. (2013) Effects of a short-term carbohydrate-restricted diet on strength and power performance. J Strength Cond Res 27, 2255-2262.

33. Dipla K, Makri M, Zafeiridis A, et al. (2008) An isoenergetic high-protein, moderate-fat diet does not compromise strength and fatigue during resistance exercise in women. $\mathrm{Br}$ J Nutr 100, 283-286.

34. Roberts MD, Holland AM, Kephart WC, et al. (2016) A putative low-carbohydrate ketogenic diet elicits mild nutritional ketosis but does not impair the acute or chronic hypertrophic responses to resistance exercise in rodents. J Appl Physiol (1985) 120, 1173-1185.

35. Costill DL \& Hargreaves M (1992) Carbohydrate nutrition and fatigue. Sports Med 13, 86-92.

36. Robergs RA, Pearson DR, Costill DL, et al. (1991) Muscle glycogenolysis during differing intensities of weightresistance exercise. J Appl Physiol 70, 1700-1706.

37. Camera DM, Edge J, Short MJ, et al. (2010) Early time course of Akt phosphorylation after endurance and resistance exercise. Med Sci Sports Exerc 42, 1843-1852. 
38. Paoli A, Grimaldi K, D’Agostino D, et al. (2012) Ketogenic diet does not affect strength performance in elite artistic gymnasts. J Int Soc Sports Nutr 9, 34 .

39. Leveritt M \& Abernathy PJ (1999) Effects of carbohydrate restriction on strength performance. J Strength Cond Res 13, 6 .

40. Van Zant RS, Conway JM \& Seale JL (2002) A moderate carbohydrate and fat diet does not impair strength performance in moderately trained males. J Sports Med Phys Fitness 42, 31-37.

41. Churchley EG, Coffey VG, Pedersen DJ, et al. (2007) Influence of preexercise muscle glycogen content on transcriptional activity of metabolic and myogenic genes in well-trained humans. J Appl Physiol 102, 1604-1611.

42. Camera DM, Hawley JA \& Coffey VG (2015) Resistance exercise with low glycogen increases p 53 phosphorylation and PGC-1alpha mRNA in skeletal muscle. EurJ Appl Physiol 115, 1185-1194.

43. Haff GG \& Whitley A (2002) Low-carbohydrate diets and high-intensity anaerobic exercise. Strength Cond J 24, 12.

44. Hatfield DL, Kraemer WJ, Volek JS, et al. (2006) The effects of carbohydrate loading on repetitive jump squat power performance. J Strength Cond 20, 167-171.

45. Roy BD \& Tarnopolsky MA (1998) Influence of differing macronutrient intakes on muscle glycogen resynthesis after resistance exercise. I Appl Physiol 84, 890-896.

46. Pascoe DD \& Gladden LB (1996) Muscle glycogen resynthesis after short term, high intensity exercise and resistance exercise. Sports Med 21, 98-118.

47. Aragon AA \& Schoenfeld BJ (2013) Nutrient timing revisited: is there a post-exercise anabolic window? J Int Soc Sports Nutr 10, 5 .

48. Aschenbach WG, Sakamoto K \& Goodyear LJ (2004) 5 adenosine monophosphate-activated protein kinase, metabolism and exercise. Sports Med 34, 91-103.

49. McBride A, Ghilagaber S, Nikolaev A, et al. (2009) The glycogen-binding domain on the AMPK beta subunit allows the kinase to act as a glycogen sensor. Cell Metab 9, 23-34.

50. Coffey VG \& Hawley JA (2007) The molecular bases of training adaptation. Sports Med 37, 737-763.

51. Hawley JA, Hargreaves M \& Zierath JR (2006) Signalling mechanisms in skeletal muscle: role in substrate selection and muscle adaptation. Essays Biochem 42, 1-12.

52. Jorgensen SB, Richter EA \& Wojtaszewski JF (2006) Role of AMPK in skeletal muscle metabolic regulation and adaptation in relation to exercise. J Physiol 574, 17-31.

53. Bolster DR, Crozier SJ, Kimball SR, et al. (2002) AMPactivated protein kinase suppresses protein synthesis in rat skeletal muscle through down-regulated mammalian target of rapamycin (mTOR) signaling. J Biol Chem 277, 23977-23980.

54. Xu J, Ji J \& Yan XH (2012) Cross-talk between AMPK and mTOR in regulating energy balance. Crit Rev Food Sci Nutr 52, 373-381.

55. Goodman CA, Mayhew DL \& Hornberger TA (2011) Recent progress toward understanding the molecular mechanisms that regulate skeletal muscle mass. Cell Signal 23, 1896-1906.

56. Sandri M (2013) Protein breakdown in muscle wasting: role of autophagy-lysosome and ubiquitin-proteasome. Int $J$ Biochem Cell Biol 45, 2121-2129.

57. Dreyer HC, Fujita S, Cadenas JG, et al. (2006) Resistance exercise increases AMPK activity and reduces 4E-BP1 phosphorylation and protein synthesis in human skeletal muscle. J Physiol 576, 613-624.

58. Williamson DL, Bolster DR, Kimball SR, et al. (2006) Time course changes in signaling pathways and protein synthesis in $\mathrm{C} 2 \mathrm{C} 12$ myotubes following AMPK activation by AICAR. Am J Physiol Endocrinol Metab 291, E80-E89.

59. Lundberg TR, Fernandez-Gonzalo R \& Tesch PA (2014) Exercise-induced AMPK activation does not interfere with muscle hypertrophy in response to resistance training in men. J Appl Physiol 116, 611-620.

60. Wilkinson SB, Phillips SM, Atherton PJ, et al. (2008) Differential effects of resistance and endurance exercise in the fed state on signalling molecule phosphorylation and protein synthesis in human muscle. J Physiol 586, 3701-3717.

61. McBride A \& Hardie DG (2009) AMP-activated protein kinase - a sensor of glycogen as well as AMP and ATP? Acta Physiol 196, 99-113.

62. Carling D, Mayer FV, Sanders MJ, et al. (2011) AMP-activated protein kinase: nature's energy sensor. Nat Chem Biol $\mathbf{7}$, 512-518.

63. Wojtaszewski JF, MacDonald C, Nielsen JN, et al. (2003) Regulation of 5'AMP-activated protein kinase activity and substrate utilization in exercising human skeletal muscle. Am J Physiol Endocrinol Metab 284, E813-E822.

64. Steinberg GR, Watt MJ, McGee SL, et al. (2006) Reduced glycogen availability is associated with increased AMPKalpha2 activity, nuclear AMPKalpha2 protein abundance, and GLUT4 mRNA expression in contracting human skeletal muscle. Appl Physiol, Nutr Metab 31, 302-312.

65. Watt MJ, Steinberg GR, Chan S, et al. (2004) Beta-adrenergic stimulation of skeletal muscle HSL can be overridden by AMPK signaling. FASEB J 18, 1445-1446.

66. Roepstorff C, Vistisen B, Donsmark M, et al. (2004) Regulation of hormone-sensitive lipase activity and Ser563 and Ser565 phosphorylation in human skeletal muscle during exercise. J Physiol 560, 551-562.

67. Paoli A, Bianco A \& Grimaldi KA (2015) The ketogenic diet and sport: a possible marriage? Exerc Sports Sci Rev $\mathbf{4 3}$, 153-162.

68. Yeo WK, McGee SL, Carey AL, et al. (2010) Acute signalling responses to intense endurance training commenced with low or normal muscle glycogen. Exper Physiol 95, 351-358.

69. Polekhina G, Gupta A, Michell BJ, et al. (2003) AMPK beta subunit targets metabolic stress sensing to glycogen. Curr Biol 13, 867-871.

70. Ivy JL, Ding Z, Hwang H, et al. (2008) Post exercise carbohydrate-protein supplementation: phosphorylation of muscle proteins involved in glycogen synthesis and protein translation. Amino Acids 35, 89-97.

71. Chow LS, Albright RC, Bigelow ML, et al. (2006) Mechanism of insulin's anabolic effect on muscle: measurements of muscle protein synthesis and breakdown using aminoacyl-tRNA and other surrogate measures. Am J Physiol Endocrinol Metab 291, E729-E736.

72. Fujita S, Dreyer HC, Drummond MJ, et al. (2007) Nutrient signalling in the regulation of human muscle protein synthesis. J Physiol 582, 813-823.

73. Trommelen J, Groen BB, Hamer HM, et al. (2015) Mechanisms in endocrinology: exogenous insulin does not increase muscle protein synthesis rate when administered systemically: a systematic review. Eur J Endocrinol 173, R25-R34.

74. Fujita S, Rasmussen BB, Cadenas JG, et al. (2006) Effect of insulin on human skeletal muscle protein synthesis is modulated by insulin-induced changes in muscle blood flow and amino acid availability. Am J Physiol Endocrinol Metab 291, E745-E754.

75. Bell JA, Volpi E, Fujita S, et al. (2006) Skeletal muscle protein anabolic response to increased energy and insulin is preserved in poorly controlled type 2 diabetes. J Nutr 136, 1249-1255. 
76. Abdulla H, Smith K, Atherton PJ, et al. (2016) Role of insulin in the regulation of human skeletal muscle protein synthesis and breakdown: a systematic review and meta-analysis. Diabetologia 59, 44-55.

77. Morton RW, McGlory C \& Phillips SM (2015) Nutritional interventions to augment resistance training-induced skeletal muscle hypertrophy. Front Physiol 6, 245.

78. Staples AW, Burd NA, West DW, et al. (2011) Carbohydrate does not augment exercise-induced protein accretion versus protein alone. Med Sci Sports Exerc 43, 1154-1161.

79. Hornberger TA, Stuppard R, Conley KE, et al. (2004) Mechanical stimuli regulate rapamycin-sensitive signalling by a phosphoinositide 3-kinase-, protein kinase B- and growth factor-independent mechanism. Biochem $J \mathbf{3 8 0}$, 795-804

80. Spangenburg EE, Le Roith D, Ward CW, et al. (2008) A functional insulin-like growth factor receptor is not necessary for load-induced skeletal muscle hypertrophy. J Physiol 586, 283-291.

81. West DW, Burd NA, Staples AW, et al. (2010) Human exercise-mediated skeletal muscle hypertrophy is an intrinsic process. Int J Biochem Cell Biol 42, 1371-1375.

82. Latres E, Amini AR, Amini AA, et al. (2005) Insulin-like growth factor-1 (IGF-1) inversely regulates atrophy-induced genes via the phosphatidylinositol 3-kinase/Akt/mammalian target of rapamycin (PI3K/Akt/mTOR) pathway. J Biol Chem 280, 2737-2744.

83. Stitt TN, Drujan D, Clarke BA, et al. (2004) The IGF-1/PI3K/ Akt pathway prevents expression of muscle atrophyinduced ubiquitin ligases by inhibiting FOXO transcription factors. Mol Cell 14, 395-403.

84. Lee SW, Dai G, Hu Z, et al. (2004) Regulation of muscle protein degradation: coordinated control of apoptotic and ubiquitin-proteasome systems by phosphatidylinositol 3 kinase. J Am Soc N 15, 1537-1545.

85. Mikura M, Yamaoka I, Doi M, et al. (2009) Glucose infusion suppresses surgery-induced muscle protein breakdown by inhibiting ubiquitin-proteasome pathway in rats. Anesthesiology 110, 81-88.

86. van der Vos KE, Eliasson P, Proikas-Cezanne T, et al. (2012) Modulation of glutamine metabolism by the PI(3)K-PKB-FOXO network regulates autophagy. Nat Cell Biol 14, 829-837.

87. Meijer AJ, Lorin S, Blommaart EF, et al. (2015) Regulation of autophagy by amino acids and MTOR-dependent signal transduction. Amino Acids 47, 2037-2063.

88. Bird SP, Tarpenning KM \& Marino FE (2006) Liquid carbohydrate/essential amino acid ingestion during a short-term bout of resistance exercise suppresses myofibrillar protein degradation. Metabolism 55, 570-577.

89. Bird SP, Tarpenning KM \& Marino FE (2006) Independent and combined effects of liquid carbohydrate/essential amino acid ingestion on hormonal and muscular adaptations following resistance training in untrained men. Eur J Appl Physiol 97, 225-238.

90. Greenhaff PL, Karagounis LG, Peirce N, et al. (2008) Disassociation between the effects of amino acids and insulin on signaling, ubiquitin ligases, and protein turnover in human muscle. Am J Physiol Endocrinol Metab 295, E595-E604.

91. Candow DG, Burke NC, Smith-Palmer T, et al. (2006) Effect of whey and soy protein supplementation combined with resistance training in young adults. Int I Sport Nutr Exerc Metab 16, 233-244.

92. Cribb PJ, Williams AD \& Hayes A (2007) A creatine-proteincarbohydrate supplement enhances responses to resistance training. Med Sci Sports Exerc 39, 1960-1968.
93. Rahbek SK, Farup J, Moller AB, et al. (2014) Effects of divergent resistance exercise contraction mode and dietary supplementation type on anabolic signalling, muscle protein synthesis and muscle hypertrophy. Amino Acids $\mathbf{4 6}$, 2377-2392.

94. Hornberger TA, Chu WK, Mak YW, et al. (2006) The role of phospholipase D and phosphatidic acid in the mechanical activation of mTOR signaling in skeletal muscle. Proc Natl Acad Sci U S A 103, 4741-4746.

95. Joy JM, Gundermann DM, Lowery RP, et al. (2014) Phosphatidic acid enhances mTOR signaling and resistance exercise induced hypertrophy. Nutr Metab 11, 29.

96. Apro W, Moberg M, Hamilton DL, et al. (2015) Resistance exercise-induced S6K1 kinase activity is not inhibited in human skeletal muscle despite prior activation of AMPK by high-intensity interval cycling. Am J Physiol Endocrinol Metab 308, E470-E481.

97. Coffey VG, Zhong Z, Shield A, et al. (2006) Early signaling responses to divergent exercise stimuli in skeletal muscle from well-trained humans. FASEB J 20, 190-192.

98. Areta JL, Burke LM, Ross ML, et al. (2013) Timing and distribution of protein ingestion during prolonged recovery from resistance exercise alters myofibrillar protein synthesis. J Physiol 591, 2319-2331.

99. Churchward-Venne TA, Murphy $\mathrm{CH}$, Longland TM, et al. (2013) Role of protein and amino acids in promoting lean mass accretion with resistance exercise and attenuating lean mass loss during energy deficit in humans. Amino Acids $\mathbf{4 5}$, 231-240.

100. Tipton KD, Borsheim E, Wolf SE, et al. (2003) Acute response of net muscle protein balance reflects 24-h balance after exercise and amino acid ingestion. Am J Physiol Endocrinol Metab 284, E76-E89.

101. Burd NA, West DW, Moore DR, et al. (2011) Enhanced amino acid sensitivity of myofibrillar protein synthesis persists for up to $24 \mathrm{~h}$ after resistance exercise in young men. J Nutr 141, 568-573.

102. Tipton KD, Gurkin BE, Matin S, et al. (1999) Nonessential amino acids are not necessary to stimulate net muscle protein synthesis in healthy volunteers. J Nutr Biochem 10, 89-95.

103. Phillips SM, Tang JE \& Moore DR (2009) The role of milkand soy-based protein in support of muscle protein synthesis and muscle protein accretion in young and elderly persons. $J$ Am Coll Nutr 28, 343-354.

104. Kimball SR \& Jefferson LS (2005) Role of amino acids in the translational control of protein synthesis in mammals. Semin Cell Dev Biol 16, 21-27.

105. Deldicque L, Theisen D \& Francaux M (2005) Regulation of mTOR by amino acids and resistance exercise in skeletal muscle. Eur J Appl Physiol 94, 1-10.

106. Meijer AJ, Lorin S, Blommaart EF, et al. (2015) Regulation of autophagy by amino acids and MTOR-dependent signal transduction. Amino Acids 47, 2037-2063.

107. Bar-Peled L \& Sabatini DM (2014) Regulation of mTORC1 by amino acids. Trends Cell Biol 24, 400-406.

108. Efeyan A, Zoncu R, Chang S, et al. (2013) Regulation of mTORC1 by the Rag GTPases is necessary for neonatal autophagy and survival. Nature 493, 679-683.

109. Sancak Y, Bar-Peled L, Zoncu R, et al. (2010) Ragulator-Rag complex targets mTORC1 to the lysosomal surface and is necessary for its activation by amino acids. Cell 141, 290-303.

110. Kanazawa T, Taneike I, Akaishi R, et al. (2004) Amino acids and insulin control autophagic proteolysis through different signaling pathways in relation to mTOR in isolated rat hepatocytes. J Biol Chem 279, 8452-8459. 
111. Sugawara T, Ito Y, Nishizawa N, et al. (2009) Regulation of muscle protein degradation, not synthesis, by dietary leucine in rats fed a protein-deficient diet. Amino Acids 37, 609-616.

112. Herningtyas EH, Okimura $\mathrm{Y}$, Handayaningsih $\mathrm{AE}$, et al. (2008) Branched-chain amino acids and arginine suppress MaFbx/atrogin-1 mRNA expression via mTOR pathway in C2C12 cell line. Biochim Biophys Acta 1780, 1115-1120.

113. Sadiq F, Hazlerigg DG \& Lomax MA (2007) Amino acids and insulin act additively to regulate components of the ubiquitin-proteasome pathway in $\mathrm{C} 2 \mathrm{C} 12$ myotubes. $\mathrm{BMC} \mathrm{Mol}$ Biol 8, 23.

114. Moore DR, Robinson MJ, Fry JL, et al. (2009) Ingested protein dose response of muscle and albumin protein synthesis after resistance exercise in young men. Am J Clin Nutr 89, 161-168.

115. Yang Y, Churchward-Venne TA, Burd NA, et al. (2012) Myofibrillar protein synthesis following ingestion of soy protein isolate at rest and after resistance exercise in elderly men. Nutr Metab 9, 57.

116. Moore DR, Areta J, Coffey VG, et al. (2012) Daytime pattern of post-exercise protein intake affects whole-body protein turnover in resistance-trained males. Nutr Metab 9, 91.

117. Harber MP, Schenk S, Barkan AL, et al. (2005) Effects of dietary carbohydrate restriction with high protein intake on protein metabolism and the somatotropic axis. J Clin Endocrinol Metab 90, 5175-5181.

118. Robinson SM, Jaccard C, Persaud C, et al. (1990) Protein turnover and thermogenesis in response to high-protein and high-carbohydrate feeding in men. Am J Clin Nutr 52, 72-80.

119. Biolo G, Maggi SP, Williams BD, et al. (1995) Increased rates of muscle protein turnover and amino acid transport after resistance exercise in humans. Am J Physiol 268, E514-E520.
120. Chesley A, MacDougall JD, Tarnopolsky MA, et al. (1992) Changes in human muscle protein synthesis after resistance exercise. J Appl Physiol 73, 1383-1388.

121. Phillips SM, Tipton KD, Aarsland A, et al. (1997) Mixed muscle protein synthesis and breakdown after resistance exercise in humans. Am J Physiol 273, E99-E107.

122. Moore DR, Tang JE, Burd NA, et al. (2009) Differential stimulation of myofibrillar and sarcoplasmic protein synthesis with protein ingestion at rest and after resistance exercise. J Physiol 587, 897-904.

123. MacDougall JD, Gibala MJ, Tarnopolsky MA, et al. (1995) The time course for elevated muscle protein synthesis following heavy resistance exercise. Canadian J Appl Physiol 20, 480-486.

124. Churchward-Venne TA, Burd NA \& Phillips SM (2012) Nutritional regulation of muscle protein synthesis with resistance exercise: strategies to enhance anabolism. Nutr Metab 9, 40.

125. Drummond MJ, Miyazaki M, Dreyer HC, et al. (2009) Expression of growth-related genes in young and older human skeletal muscle following an acute stimulation of protein synthesis. J Appl Physiol 106, 1403-1411.

126. Phillips SM (2014) A brief review of higher dietary protein diets in weight loss: a focus on athletes. Sports Med $\mathbf{4 4}$, Suppl. 2, S149-S153.

127. Tipton KD, Ferrando AA, Phillips SM, et al. (1999) Postexercise net protein synthesis in human muscle from orally administered amino acids. Am J Physiol 276, E628-E634.

128. Kraemer WJ, Adams K, Cafarelli E, et al. (2002) American College of Sports Medicine position stand. Progression models in resistance training for healthy adults. Med Sci Sports Exerc 34, 364-380. 